\title{
Profile of cyclists with head injury admitted to a London Major Trauma Centre
}

\author{
Anna E Forbes*, John M Schutzer-Weissmann, Matthew Wordsworth, Mark H Wilson \\ From London Trauma Conference 2014 \\ London, UK. 9-12 December 2014
}

\section{Background}

As the number of cyclists in Britain continues to grow [1], interest in cycle safety has increased. The aim of this study was to identify patient characteristics, mechanisms of injury and injury patterns in cyclists with head injury admitted to a London Major Trauma Centre with a view to identifying factors which could increase cycle safety.

\section{Methods}

Cyclists with any head injury requiring admission to hospital between January $1^{\text {st }} 2011$ and December $31^{\text {st }}$ 2013 were identified from Intensive Care admissions, Emergency Department records, the Trauma Audit and Research Network and patient lists for the Trauma Ward.

After identification of the patient group, data was collected from emergency department and pre-hospital documentation, imaging, toxicology and Intensive Care documentation where relevant.

\section{Results}

93 patients were identified with an average age of 37 . $89 \%$ were male. $54 \%$ were not wearing helmets, $20 \%$ were wearing helmets and helmet use was not recorded for $26 \%$. The most common mechanisms of injury were cyclists vs car (41\%) and falls (38\%).

There was no pattern of laterality in terms of intracranial or extracranial injuries. In those with intracranial injury 53\% sustained contusions, $49 \%$ Subarachnoid haemorrhage, 38\% subdural haematoma (SDH) and 23\% extradural haematoma (EDH). Where helmet use was recorded no patients wearing a helmet sustained an EDH and only 1 had a SDH.

\footnotetext{
* Correspondence: aeaforbes@gmail.com

Intensive Care Unit and Major Trauma Ward, St Mary's Hospital, Imperial College Healthcare NHS Trust, London, UK
}

(c) 2015 Forbes et al. This is an Open Access article distributed under the terms of the Creative Commons Attribution License (http:// creativecommons.org/licenses/by/4.0), which permits unrestricted use, distribution, and reproduction in any medium, provided the original work is properly cited. The Creative Commons Public Domain Dedication waiver (http://creativecommons.org/publicdomain/ zero/1.0/) applies to the data made available in this article, unless otherwise stated.

\section{and take full advantage of:}

- Convenient online submission

- Thorough peer review

- No space constraints or color figure charges

- Immediate publication on acceptance

- Inclusion in PubMed, CAS, Scopus and Google Scholar

- Research which is freely available for redistribution 